\title{
PENGARUH PENGUNGKAPAN CORPORATE SOCIAL RESPONSIBILITY DAN DEBT EQUITY RATIO TERHADAP PROFITABILITY PADA PERUSAHAAN PERTAMBANGAN YANG TERDAFTAR DI BURSA EFEK INDONESIA
}

\author{
Ahmad Subakti \\ Program Magister Universitas IGM Palembang \\ Email : ahmad_subakti@gmail.com \\ Harsi Romli \\ Program Magister Universitas IGM Palembang \\ Email: harsiromli@uigm.ac.id \\ DOI : 10.35908/jeg.v4i2.756
}

Received: May 29, 2019, Revised: June 17, 2019, Accepted: July 11, 2019

\begin{abstract}
This study aims to find out and analyze how the effect of disclosure of Corporate Social Responsibility and Debt Equity Ratio on the profitability of mining companies in the Indonesia Stock Exchange in the period 2012-2017. The population in this study were 41 mining companies while the study sample was 12 mining companies with a total of 72 observations selected by purposive sampling. Financial report data and annual reports are obtained from the Indo-Exchange File (IDX). The data analysis technique uses technical linear multiple regression. In this study the disclosure variables of Corporate Social Responsibility (CSR) were measured using the Corporate Social Responsibility Disclusure Index (CSRDI), the variable Debt to Equiy Ratio measured by the ratio of the proportion of debt to equity, and Profitability measured using Return On Assets (ROA). The results of the study show that the financial disclosure of financially has a positive and significant effect on profitability. While partially Debt to Equiy Ratio (DER) has a negative and significant effect on Profitability. Simultaneously, CSR and DER disclosures had a positive and significant effect on Profitability with a coefficient of determination (R2) of $32.3 \%$ while the effect of $67.7 \%$ was influenced by other variables.
\end{abstract}

Keywords: Profitability, Corporate Social Responsibility, Debt Equity Ratio.

\begin{abstract}
ABSTRAK
Penelitian ini bertujuan untuk mengetahui dan menganalisis bagaimana pengaruh pengungkapan Corporate Social Responsibility dan Debt Equity Ratio terhadap Profitability perusahaan pertambangan di Bursa Efek Indonesia periode 2012-2017. Populasi pada penelitian ini sebanyak 41 perusahaan pertambangan sedangkan sampel penelitian sebanyak 12 perusahaan pertambangan dengan jumlah pengamatan sebanyak 72 yang dipilih secara purposive sampling. Data laporan keuangan dan laporan tahunan diperoleh dari Indo-Exchange File (IDX). Teknik analisis data menggunakan teknik analisis regresi linear berganda. Dalam penelitian ini variabel pengungkapan Corporate Social Responsibility (CSR) diukur menggunakan Corporate Social Responsibility Disclusure Index (CSRDI), variable Debt to Equiy Ratio diukur dengan rasio proporsi utang terhadap ekuitas, dan Profitability diukur dengan menggunakan Return On Assets(ROA). Hasil penelitian menunjukkan bahwa secara parsial pengungkapan CSR berpengaruh positif dan signifikan terhadap Profitability. Sedangkan secara parsial Debt to Equity Ratio (DER) berpengaruh negatif dan signifikan terhadap Profitability. Secara simultan, pengungkapan CSR dan DER berpengaruh positif
\end{abstract}


dan signifikan terhadap Profitability dengan nilai koefisien determinasi $\left(\mathrm{R}^{2}\right)$ sebesar 32,3\% sedangkan sisanya $67,7 \%$ dipengaruhi oleh variabel lain.

Kata kunci: Profitability, Corporate Social Responsibility, Debt Equity Ratio.

\section{Pendahuluan}

\subsection{Latar Belakang}

Beberapa tahun lalu kinerja keuangan perusahaan pertambangan di Indonesia menjadi sorotan publik khususnya di tahun 2015 yang mengalami banyak kerugian baik di sektor batu bara, sektor minyak bumi dan gas, logam dan mineral maupun sektor batu-batuan sehingga menyebabkan penurunan kinerja keuangan yang signifikan dari tahun tahun sebelumnya. Menurut Winzenried (2016), mengatakan bahwa kapitalisasi pasar keseluruhan perusahaan pertambangan Indonesia yang tercatat di Bursa Efek Indonesia turun dari Rp255 triliun pada tanggal 31 Desember 2014 menjadi Rp161 triliun pada tanggal 31 Desember 2015, penurunan sebesar $37 \%$ ini terutama dipicu oleh jatuhnya harga komoditas. Perusahaan tambang Indonesia dalam masa-masa ini selain berjuang mengatasi masalah lemahnya harga komoditi juga menurunnya permintaan dari Tiongkok dan negara berkembang lainnya yang menyebabkan penurunan yang signifikan atas kinerja keuangan perusahaan pertambangan di Indonesia.

Adanya fenomena tersebut tentu saja perusahaan pertambangan harus melakukan penilaian kinerja agar selektif dalam mengambil keputusan. Menurut Fahmi (2013:239) kinerja keuangan adalah suatu analisis yang dilakukan untuk melihat sejauh mana suatu perusahaan telah melaksanakan dengan menggunakan aturan-aturan pelaksanaan keuangan secara baik dan benar.
Profitability atau dikenal sebagai Return On Assets (selanjutnya dinyatakan dengan ROA). ROA merupakan bagian dari analisis rasio. Tujuan profitability ratio menurut Hery (2017:192) yaitu untuk mengetahui kemampuan perusahaan dalam menghasilkan laba selama periode tertentu, dan bertujuan untuk mengukur tingkat efektifitas manajemen dalam menjalankan operasional perusahaan.

Namun dilihat dari fenomena yang terjadi membuktikan bahwa perusahaan pertambangan mengalami penurunan pada kinerja keuangan dari tahun 2012-2015 dan terjadi peningkatan di tahun 20162017 pada kinerja keuangan yang dihitung dengan menggunakan rasio ROA. Penurunan dan peningkatan kinerja keuangan dapat dilihat dari grafik di bawah ini:

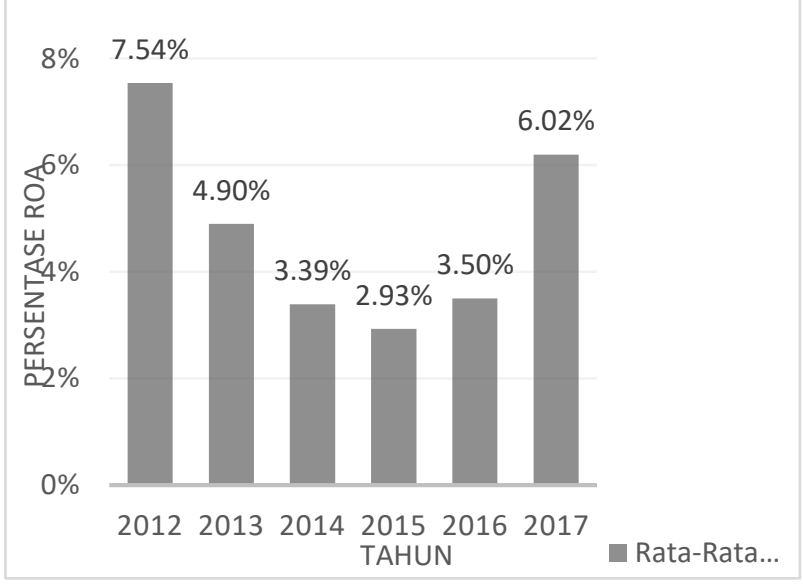

\section{Gambar 1.1}

\section{Kinerja Keuangan Pertambangan}

Menurut Kasmir (2016:208) bahwa ROA juga disebut juga sebagai Return On Investment (ROI) dan dari hasil pengukuran standar industri ROI adalah sebesar $30 \%$. Pada grafik kinerja keuangan 
pertambangan di atas menunjukkan bahwa pada tahun 2012 merupakan tahun yang memperoleh kinerja yang tertinggi namun tidak mencapai batas rata-rata ROA yaitu 30\%, begitu juga pada tahun 2013 yang menunjukkan penurunan sebesar $2,64 \%$ dari tahun 2012, diikuti pada tahun 2014 juga mengalami penurunan sebesar $1,51 \%$ dari tahun 2013, dan tahun 2015 merupakan tahun yang mengalami penurunan yang sangat signifikan dibandingkan tahun 2012-2014 pada tahun ini sebanyak 20 perusahaan yang mengalami kerugian yang dapat menyebabkan penurunan kinerja namun tidak untuk pada tahun 2016 dimana pada tahun ini harga komoditas yang cukup membaik sehingga adanya peningkatan sebesar 0,57 dari tahun 2015, dan pada tahun 2017 juga mengalami peningkatan terhadap kinerja keuangan yaitu sebesar 2,52\% dari tahun 2016. Jadi dapat ditarik kesimpulan bahwa tingkat profitabilitas perusahaan pertambangan pada tahun 2012-2017 belum mencapai standar industri yang diungkapkan oleh Kasmir (2016:208).

\section{Pengungkapan Corporate Sosial} Responsibility (CSR disclosure) menjadi isu penting bagi perusahaan dan merupakan media informasi untuk pengambilan keputusan oleh investor. Isu ini dipicu oleh ulah perilaku bisnis yang tidak etis dan tidak ramah lingkungan yang pada dasarnya memiliki tujuan utama untuk dapat memperoleh keuntungan yang sebesar-besarnya tanpa memperhatikan dampak sosial dan lingkungan yang ditimbulkan oleh aktivitas ekonomi perusahaan Andreas, dkk (2015:119)

Menurut Binangkit dan Raharjo (2014:27) struktur modal adalah perpaduan dari nilai utang dan nilai modal sendiri (saham preferen, saham biasa, dan saldo laba) yang tercermin pada laporan keuangan perusahaan akhir tahun. Perpaduan nilai utang dan modal sendiri dapat diukur dengan menggunakan Debt to Equity Ratio (selanjutnya dinyatakan dengan DER). Hery (2017:168) DER berfungsi untuk mengetahui berapa bagian dari setiap rupiah modal yang dijadikan sebagai jaminan utang. Dengan kata lain, akan lebih aman bagi kreditor apabila memberikan pinjaman kepada debitor yang memiliki DER yang rendah karena hal ini berarti akan semakin besar jumlah modal pemilik yang dapat dijadikan sebagai jaminan utang Hery (2017:169).

Menurut Fadhilah (2012:2) para pemilik perusahaan sangat concern terhadap keputusan struktur modal karena akan berpengaruh pada kinerja perusahaan yang pada akhirnya akan menentukan tingkat pengembalian atas modal yang diinvestasikannya. Jika dilihat dari perusahaan pertambangan, berdasarkan Undang-Undang No.4 Tahun 2009 pasal 103 ayat 1 menyatakan bahwa pemegang IUP dan IUPK Operasi Produksi wajib melakukan pengolahan dan pemurnian hasil penambangan di dalam negeri dengan peraturan tersebut membuat perusahaan pertambangan harus membangun industri pengolahan produk tambang mentah (smelter) yang mengeluarkan biaya yang tidak sedikit. Sehingga dana yang diperlukan selain dari pihak internal juga melibatkan pihak eksternal. Kepadatan modal dan risiko perusahaan serta harga komoditas pertambangan menyebabkan ketidakstabilan tingkat utang perusahaan pertambangan dari tahun 2012-2017 yang diukur dengan DER dapat dilihat pada grafik di bawah ini: 


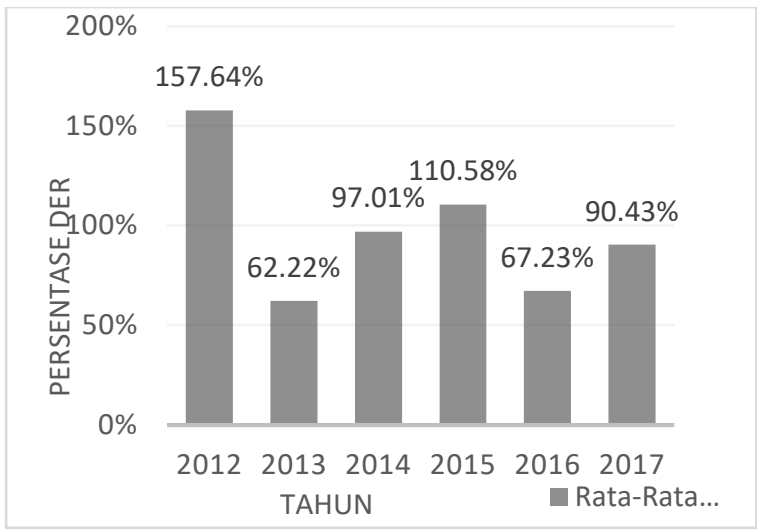

Sumber: www.idx.co.id, (Data diolah,2018)

\section{Gambar 1.2}

Tingkat Utang Pertambangan

Menurut Kasmir (2016:164) standar industri untuk rasio DER adalah $80 \%$. Pada grafik diatas menunjukkan bahwa adanya ketidakstabilan tingkat utang pada perusahaan pertambangan tahun 2012-2017 yang di ukur dengan DER.

Berbagai fenomena dan tantangan yang terjadi pada perusahaan pertambangan di Indonesia yang telah dijelaskan diatas maka perusahaan harus memiliki kinerja keuangan yang baik agar mampu bertahan, bersaing, dan mencapai tujuan perusahaan serta diharapkan dapat memberikan gambaran tentang kondisi keuangan yang dapat dijadikan sebagai pengambilan keputusan. Berdasarkan uraian tersebut serta penelitian terdahulu penulis tertarik untuk melakukan penelitian dengan judul "Pengaruh Pengungkapan Corporate Social Responsibility dan Debt Equity Ratio terhadap Profitability pada Perusahaan Pertambangan yang Terdaftar di Bursa Efek Indonesia"

\subsection{Rumusan Masalah}

Berdasarkan identifikasi masalah yang telah dijelaskan diatas, maka dapat dirumuskan permasalahan dalam penelitian, yaitu:
1. Bagaimanakah pengaruh pengungkapan Corporate Social Responsibility terhadap Profitability secara parsial pada perusahaan pertambangan yang terdaftar di Bursa Efek Indonesia?

2. Bagaimanakah pengaruh Debt Equity Ratio terhadap Profitability secara parsial pada perusahaan pertambangan yang terdaftar di Bursa Efek Indonesia?

3. Bagaimanakah pengaruh pengungkapan Corporate Social Responsibility dan Debt Equity Ratio secara simultan terhadap Profitability pada perusahaan pertambangan yang terdaftar di Bursa Efek Indonesia?

\subsection{Tujuan Penelitian}

Tujuan dari penelitian ini adalah sebagai berikut:

1. Untuk menganalisis pengaruh pengungkapan Corporate Social Responsibility terhadap Profitability pada perusahaan pertambangan yang terdaftar di Bursa Efek Indonesia.

2. Untuk menganalisis pengaruh Debt Equity Ratio terhadap Profitability pada perusahaan pertambangan yang terdaftar di Bursa Efek Indonesia.

3. Untuk menganalisis pengaruh pengungkapan Corporate Social Responsibility dan Debt Equity Ratio secara simultan terhadap Profitability pada perusahaan pertambangan yang terdaftar di Bursa Efek Indonesia.

\subsection{Metodologi Penelitian}

Dalam penelitian ini model analisis yang digunakan adalah regresi berganda karena penelitian ini dirancang untuk 
meneliti pengaruh variabel independen dan variabel dependen.

\subsubsection{Teknik Analisis Data}

Penelitian menggunakan pendekatan kuantitatif dan metode analisis yang digunakan dalam penelitian ini yaitu analisis statistik yang perhitungannya dilakukan dengan menggunakan SPSS (Statistical Product and Service Solution) Versi 20.0. Analisis ini bertujuan untuk menentukan pengaruh hubungan antara index pengungkapan Corporate Social Responsibility (CSR) dan Debt Equity Ratio (DER) terhadap Profitability.

\subsubsection{Uji Normalitas}

Uji normalitas data bertujuan untuk menguji apakah dalam model regresi, variabel pengganggu atau residual memiliki distribusi normal. Dasar pengambilan keputusan dalam melihat penyebaran data (titik) pada sumbu diagonal dari grafik normal probability plotadalah:

a. Jika data menyebar di sekitar garis diagonal dan mengikuti arah garis diagonal, maka model regresi memenuhi asumsi normalitas.

b. Jika data menyebar jauh dari garis diagonal dan/atau mengikuti arah garis diagonal, maka model regresi tidak mampu memenuhi asumsiasumsi normalitas.

Uji normalitas lainnya yang digunakan adalah uji KolmogorovSmirnov. Menurut Ghozali (2013)bahwa distribusi data dapat dilihat dengan membandingkan $\mathrm{Z}$ hitung dengan $\mathrm{Z}$ tabel dengan kriteria sebagai berikut:
a. Jika
nilai
probabilitas
(Kolmogorov-Smirnov) > taraf

signifikansi $5 \% \quad(0,05)$, maka distribusi data dikatakan normal.

b. Jika nilai probabilitas (KolmogorovSmirnov) < taraf signifikansi $5 \%$ $(0,05)$, maka distribusi data dikatakan tidak normal.

\subsubsection{Uji Heteroskedastisitas}

Menurut Silalahi dan Ardini (2017:10) cara untuk mendeteksi ada atau tidaknya heteroskedastisitas yaitu dengan melihat grafik plot antara nilai prediksi variabel terikat (dependen). Deteksi ada tidaknya pola tertentu pada grafik scatterplot dimana sumbu $\mathrm{Y}$ adalah $\mathrm{Y}$ yang telah diprediksi, dan sumbu $\mathrm{X}$ adalah residual ( $\mathrm{Y}$ prediksi $-\mathrm{Y}$ sesungguhnya) yang telah di-stadentized.

a. Jika ada pola tertentu, seperti titiktitik yang ada membentuk pola tertentu yang teratur (bergelombang, melebar kemudian, menyempit), maka mengindikasikan telah terjadi heteroskedastisitas.

b. Jika tidak ada pola yang jelas, serta titik-titik menyebar di atas dan di bawah angka 0 pada sumbu $\mathrm{Y}$, maka tidak terjadi heteroskedastisitas.

\subsubsection{Uji Autokorelasi}

Uji autokorelasi bertujuan unuk menguji apakah dalam suatu model regresi linear ada korelasi antara kesalahan penganggu pada periode $\mathrm{t}$ dengan kesalahan pengganggu pada periode $\mathrm{t}-1$.

\subsubsection{Uji multikolinearitas}

Uji multikolinearitas bertujuan untuk menguji apakah model regresi 
ditemukan adanya korelasi antar variabel bebas atau variabel independen. Model regresi yang baik seharusnya tidak terjadi korelasi diantara variabel independen dan perhitungan nilai tolerance serta Variance Inflation Factor (VIF).

\subsubsection{Uji F dan Uji t}

Uji $F$ untuk menguji pengaruh variabel independen terhadap variabel dependen secara simultan sedangkan uji $\mathrm{t}$ untuk menguji pengaruh variabel independen terhadap variabel dependen secara parsial .

\section{Pemahaman}

\subsection{Modigliani-Miller Theory}

Teori struktur modal dapat dijabarkan melalui pendekatan ketidakrelevanan hutang (Modigliani dan Miller, 1958). Modigliani dan Miller (1958) memperkenalkan teori struktur modal dengan beberapa asumsi sebagai berikut:

1. Nilai perusahaan tidak dipengaruhi oleh struktur modal. Nilai perusahaan leverage dan unleverage bernilai sama.

2. Semua investor memiliki expected return yang sama untuk perusahaan yang berbeda tetapi di kelas yang sama.

3. Saham dan obligasi perusahaan diperdagangkan di pasar sempurna atau strong capital market.

Modigliani dan Miller berasumsi bahwa perusahaan tidak bisa mengubah total nilai dari saham beredar dengan mengubah proporsi struktur modal. Teori ini disebut juga dengan teori ketidakrelevanan hutang. Ross, et. al. (2010:493) menyatakan bahwa nilai perusahaan leverege dan unleverage sama dengan tingkat biaya modal.

\subsection{SignallingTheory}

Menurut Brigham dan Houaton (2001:36) isyarat atau signal adalah:

Suatu tindakan yang diambil perusahaan untuk memberi petunjuk bagi investor tentang bagaimana manajemen memandang prospek perusahaan. Sinyal ini berupa informasi mengenai apa yang sudah dilakukan oleh manajemen untuk merealisasikan keinginan pemilik.

Informasi yang dikeluarkan oleh perusahaan merupakan hal yang penting, karena pengaruhnya terhadap keputusan investasi pihak di luar perusahaan.

\subsection{Teori Keagenan (Agency Theory)}

Persektif teori agensi merupakan dasar yang digunakan memahami isu corporate governance dan earning management. Agensi teori mengakibatkan hubungan yang asimetri antara pemilik dan pengelola, untuk menghindari terjadi sehubungan yang asimetri tersebut dibutuhkan suatu konsep yaitu konsep Good Corporate Governance yang bertujuan untuk menjadikan perusahaan menjadi lebih sehat.

\section{4.Pengertian Corporate Social Responsibility}

Menurut Bhernadha, dkk (2017:136) “Corporate Social 
Responsibility (selanjutnya dinyatakan dengan CSR) adalah komitmen perusahaan untuk berkontribusi dalam pembangunan ekonomi berkelanjutan untuk mensejahterakan perusahaan sendiri, komunitas setempat, masyarakat pada umumnya, dan lingkungan." Pengertian CSR menurut Tiarasandy dan Triyanto (2018:680) adalah "Cara perusahaan dalam mengelola aktivitas bisnisnya baik secara sebagian maupun secara keseluruhan memiliki dampak positif bagi dirinya dan lingkungan."

Menurut The World Business Council for Sustainable Development (WBCSD) menjelaskan bahwa:

CSR atau tanggung jawab sosial perusahaan didefinisikan sebagai komitmen bisnis untuk memberikan kontribusi bagi pembangunan ekonomi berkelanjutan, melalui kerjasama dengan para karyawan serta perwakilan mereka, keluarga mereka, komunitas setempat maupun masyarakat umum untuk meningkatkan kualitas kehidupan dengan cara yang bermanfaat baik bagi bisnis sendiri maupun untuk pembangunan.

\section{Corporate Social Responsibility} Disclosure dapat dihitung dengan menggunakan Corporate Social Responsibility Disclosure Index. Secara sistematis rumus perhitungan CSRDIj menurut Yaparto, dkk (2013:6) adalah sebagai berikut:

$$
\text { CSRDIj }=\frac{\sum x i j}{78}
$$

\section{Keterangan:}

$\begin{array}{ll}\text { CSRDIj } & =\text { CSR Disclosure Index } \\ & \text { perusahaan } \mathrm{j} \\ \mathrm{Xij} & =\text { dummy variabel: } \\ & \text { 1 Jika item diungkapkan; } \\ & \text { 0 Jika item tidak diungkapkan } \\ \mathrm{Nj} & =\text { Jumlah item untuk perusahaan } \mathrm{j}, \\ \mathrm{nj} & =78\end{array}$

\subsection{Tabel Penelitian Terdahulu}

\begin{tabular}{|c|c|c|c|c|c|}
\hline \multirow{2}{*}{ No } & \multirow{2}{*}{$\begin{array}{l}\text { Nama dan } \\
\text { Tahun } \\
\text { Penelitian }\end{array}$} & \multirow{2}{*}{ Judul Penelitian } & \multicolumn{2}{|c|}{ Variabel } & \multirow{2}{*}{ Hasil Penelitian } \\
\hline & & & Persamaan & Perbedaan & \\
\hline 1. & \begin{tabular}{lr}
\multicolumn{2}{l}{ Adhiwardana } \\
dan & Daljono \\
$(2013)$ & \\
ISSN & $2337-$ \\
3806 &
\end{tabular} & $\begin{array}{l}\text { Pengaruh Corporate Social } \\
\text { Responsibility dan } \\
\text { Kepemilikan Asing } \\
\text { Terhadap Kinerja } \\
\text { Perusahaan (Studi Empiris } \\
\text { pada Perusahaan } \\
\text { Manufaktur yang Terdaftar } \\
\text { di Bursa Efek Indonesia) }\end{array}$ & $\begin{array}{l}\text { Corporate Sosial } \\
\text { Responsibility } \\
\text { sebagai variabel } \\
\text { independen }\end{array}$ & $\begin{array}{l}\text { Kepemilikan } \\
\text { Asing sebagai } \\
\text { variabel } \\
\text { independen } \\
\text { Return on Equit } \\
\text { (ROE) sebagai } \\
\text { variabel dependen }\end{array}$ & $\begin{array}{l}\text { Pengungkapan CSR } \\
\text { berpengaruh positif } \\
\text { dan signifikan } \\
\text { terhadap } \\
\text { profitabilitas } \\
\text { perusahaan. }\end{array}$ \\
\hline
\end{tabular}




\begin{tabular}{|c|c|c|c|c|c|}
\hline \multirow{2}{*}{ No } & \multirow{2}{*}{$\begin{array}{l}\text { Nama dan } \\
\text { Tahun } \\
\text { Penelitian }\end{array}$} & \multirow{2}{*}{ Judul Penelitian } & \multicolumn{2}{|c|}{ Variabel } & \multirow{2}{*}{ Hasil Penelitian } \\
\hline & & & Persamaan & Perbedaan & \\
\hline 2. & $\begin{array}{l}\text { Bhernadha, dkk } \\
\text { (2017) }\end{array}$ & $\begin{array}{l}\text { Pengaruh Corporate Social } \\
\text { Responsibility Terhadap } \\
\text { Kinerja Keuangan } \\
\text { Perusahaan (Studi Pada } \\
\text { Perusahaan Winner Of } \\
\text { Sustainability Reporting } \\
\text { Award (Sra) } 2015 \text { Yang } \\
\text { Terdaftar di PT BEI Periode } \\
\text { 2010-2014) }\end{array}$ & $\begin{array}{l}\text { Corporate Sosial } \\
\text { Responsibility } \\
\text { sebagai variabel } \\
\text { independen } \\
\text { Return on Asset } \\
\text { sebagai variabel } \\
\text { dependen }\end{array}$ & $\begin{array}{l}\text { Return on Equit } \\
\text { (ROE) sebagai } \\
\text { variabel dependen }\end{array}$ & $\begin{array}{lr}\text { CSR } & \text { berpengaruh } \\
\text { positif } & \text { dan } \\
\text { signifikan } & \text { terhadap } \\
\text { ROA. } & \end{array}$ \\
\hline 3. & $\begin{array}{l}\text { Binangkitdan } \\
\text { Raharjo (2014) } \\
\text { ISSN 2337- } \\
568 X\end{array}$ & $\begin{array}{l}\text { Pengaruh Struktur Modal } \\
\text { Terhadap Kinerja } \\
\text { Perusahaan dan Harga } \\
\text { Saham Pada Perusahaan } \\
\text { Manufaktur di Bursa Efek } \\
\text { Indonesia }\end{array}$ & $\begin{array}{l}\text { Debt to Equity } \\
\text { Rasio (DER) } \\
\text { sebagai variabel } \\
\text { independen } \\
\text { Return on } \\
\text { Assets(ROA) } \\
\text { sebagai variabel } \\
\text { dependen }\end{array}$ & $\begin{array}{l}\text { Debt to Assets } \\
\text { ratio (DAR), } \\
\text { Equity to Assets } \\
\text { Ratio (EAR) } \\
\text { variabel } \\
\text { independen } \\
\text { Harga Saham } \\
\text { sebagai variabel } \\
\text { dependen }\end{array}$ & $\begin{array}{l}\text { DER berpengaruh } \\
\text { positif dan } \\
\text { signifikan terhadap } \\
\text { kinerja perusahaan. }\end{array}$ \\
\hline 4. & Dewi (2015) & $\begin{array}{l}\text { Hubungan Corporate Sosial } \\
\text { Responsibility Dengan } \\
\text { Kinerja Keuangan Pada } \\
\text { Perusahaan Sektor Pertanian } \\
\text { dan Pertambangan Di Bursa } \\
\text { Efek Indonesia. }\end{array}$ & $\begin{array}{l}\text { Corporate Sosial } \\
\text { Responsibility } \\
\text { sebagai variabel } \\
\text { independen } \\
\\
\text { Return on Asset } \\
\text { sebagai variabel } \\
\text { dependen }\end{array}$ & $\begin{array}{l}\text { Return on Equity } \\
\text { (ROE) sebagai } \\
\text { variabel dependen }\end{array}$ & $\begin{array}{l}\text { Pengungkapan CSR } \\
\text { berpengaruh positif } \\
\text { dan signifikan } \\
\text { terhadap } r \text { kinerja } \\
\text { keuangan diukur } \\
\text { dengan ROA dan } \\
\text { ROE. }\end{array}$ \\
\hline 5. & \begin{tabular}{l}
\multicolumn{2}{l}{ Fadhilah (2012) } \\
ISSN \\
3249
\end{tabular} & $\begin{array}{l}\text { Pengaruh Struktur Modal } \\
\text { Terhadap Kinerja Keuangan } \\
\text { Perusahaan (Studi kasus } \\
\text { Pada Peru sahaan Sektor } \\
\text { Pertambangan Yang } \\
\text { Tercatat Di Bursa Efek } \\
\text { Indonesia 2005-2011) }\end{array}$ & $\begin{array}{l}\text { Struktur Modal } \\
\text { sebagai variabel } \\
\text { independen } \\
\text { Return on Asset } \\
\text { sebagai variabel } \\
\text { dependen }\end{array}$ & $\begin{array}{l}\text { Return on Equity } \\
\text { (ROE) dan Price } \\
\text { to Earnings Ratio } \\
\text { (PER) }\end{array}$ & $\begin{array}{l}\text { Rasio-rasio leverage } \\
\text { berpengaruh positif } \\
\text { dan signifikan } \\
\text { terhadap kinerja } \\
\text { keuangan yang } \\
\text { diproksikan oleh } \\
\text { ROA, ROE, dan } \\
\text { PER. }\end{array}$ \\
\hline 6. & Gantino (2016) & $\begin{array}{l}\text { Pengaruh Corporate Social } \\
\text { Responsibility Terhadap } \\
\text { Kinerja Keuangan } \\
\text { Perusahaan Manufaktur } \\
\text { yang Terdaftar di Bursa } \\
\text { Efek Indonesia periode } \\
2008-2014\end{array}$ & $\begin{array}{l}\text { Corporate Sosial } \\
\text { Responsibility } \\
\text { sebagai variabel } \\
\text { independen } \\
\\
\text { Return on Asset } \\
\text { sebagai variabel } \\
\text { dependen }\end{array}$ & $\begin{array}{l}\text { Return on Equit } \\
\text { (ROE) sebagai } \\
\text { variabel dependen }\end{array}$ & $\begin{array}{lr}\text { CSR } & \text { berpengaruh } \\
\text { positif } & \text { dan } \\
\text { signifikan } & \text { terhadap } \\
\text { ROA. } & \end{array}$ \\
\hline 7. & $\begin{array}{l}\text { Kristiana (2014) } \\
\text { ISSN 2086- } \\
7603\end{array}$ & $\begin{array}{l}\text { Kebijakan Utang Sebagai } \\
\text { Determinan Kinerja } \\
\text { Perusahaan. }\end{array}$ & $\begin{array}{l}\text { Debt to Equity } \\
\text { Rasio (DER) } \\
\text { sebagai variabel } \\
\text { independen }\end{array}$ & $\begin{array}{l}\text { Dividend Payout } \\
\text { Ratio (DPR), } \\
\text { Kepemilikan } \\
\text { institusional, }\end{array}$ & $\begin{array}{l}\text { Kebijakan utang } \\
\text { memiliki pengaruh } \\
\text { positif dan } \\
\text { signifikan terhadap }\end{array}$ \\
\hline
\end{tabular}




\begin{tabular}{|c|c|c|c|c|c|}
\hline \multirow{2}{*}{ No } & \multirow{2}{*}{$\begin{array}{c}\text { Nama dan } \\
\text { Tahun } \\
\text { Penelitian }\end{array}$} & \multirow{2}{*}{ Judul Penelitian } & \multicolumn{2}{|c|}{ Variabel } & \multirow{2}{*}{ Hasil Penelitian } \\
\hline & & & Persamaan & Perbedaan & \\
\hline & & & $\begin{array}{l}\text { Return on } \\
\text { Assets }(\mathrm{ROA}) \\
\text { sebagai variabel } \\
\text { dependen }\end{array}$ & $\begin{array}{l}\text { struktur aktiva } \\
\text { variabel } \\
\text { independen }\end{array}$ & $\begin{array}{l}\text { kinerja keuangan } \\
\text { perusahaan. }\end{array}$ \\
\hline 8. & $\begin{array}{l}\text { Kusdiyanto dan } \\
\text { Kusumaningrum } \\
(2015)\end{array}$ & $\begin{array}{l}\text { Pengaruh Good Corporate } \\
\text { Governance Dan Leverage } \\
\text { Terhadap Kinerja keuangan } \\
\text { (Studi Pada Perusahaan } \\
\text { Manufaktur Yang Terdaftar } \\
\text { di BEI Tahun 2013-2014 }\end{array}$ & $\begin{array}{l}\text { Leverage sebagai } \\
\text { variabel } \\
\text { independen }\end{array}$ & $\begin{array}{l}\text { Dewan direksi, } \\
\text { komisaris } \\
\text { independen, dan } \\
\text { komite audit } \\
\text { sebagaivariabel } \\
\text { dependen }\end{array}$ & $\begin{array}{l}\text { DER tidak } \\
\text { berpengaruh secara } \\
\text { signifikan terhadap } \\
\text { kinerja keuangan. }\end{array}$ \\
\hline 9. & $\begin{array}{l}\text { Tiarasandy, E, } \\
\text { dan Triyanto } \\
(2018) \\
\text { ISSN 2355- } \\
9357\end{array}$ & $\begin{array}{l}\text { Pengaruh Kinerja } \\
\text { Lingkungan dan Corporate } \\
\text { Social Responsibility } \\
\text { Terhadap Kinerja Finansial } \\
\text { (Studi empiris Pada } \\
\text { Perusahaan yang Terdaftar } \\
\text { di PROPER Periode 2013- } \\
\text { 2015) }\end{array}$ & $\begin{array}{l}\text { Corporate Sosial } \\
\text { Responsibility } \\
\text { sebagai variabel } \\
\text { independen } \\
\\
\text { Return on Asset } \\
\text { sebagai variabel } \\
\text { dependen }\end{array}$ & $\begin{array}{l}\text { Return on Equit } \\
\text { (ROE), Operating } \\
\text { dan Net Profit } \\
\text { Margin (NPM) } \\
\text { sebagai variabel } \\
\text { dependen }\end{array}$ & $\begin{array}{l}\text { Pengungkapan CSR } \\
\text { tidak berpengaruh } \\
\text { secara parsial } \\
\text { terhadap kinerja } \\
\text { keuangan yang } \\
\text { diproksikan oleh } \\
\text { ROA }\end{array}$ \\
\hline 10. & $\begin{array}{l}\text { Mustafa dan } \\
\text { Handayani } \\
(2014)\end{array}$ & $\begin{array}{l}\text { Pengaruh Pengungkapan } \\
\text { Corporate Sosial } \\
\text { Responsibility Terhadap } \\
\text { Kinerja Keuangan } \\
\text { Perusahaan Manufaktur }\end{array}$ & $\begin{array}{l}\text { Corporate Sosial } \\
\text { Responsibility } \\
\text { sebagai variabel } \\
\text { independen }\end{array}$ & $\begin{array}{l}\text { Return on Equit } \\
\text { (ROE), Operating } \\
\text { Profit Margin } \\
\text { (OPM),dan Net } \\
\text { Profit Margin } \\
\text { (NPM)sebagai } \\
\text { variabel dependen }\end{array}$ & $\begin{array}{l}\text { CSR tidak } \\
\text { mempunyai } \\
\text { pengaruh dan } \\
\text { signifikan terhadap } \\
\text { ROA. }\end{array}$ \\
\hline 11. & $\begin{array}{l}\text { Nainggolan \& } \\
\text { dan Pratiwi } \\
(2017) \\
\text { ISSN 2503- } \\
446 X\end{array}$ & $\begin{array}{l}\text { Analisis Faktor-Faktor } \\
\text { Yang Mempengaruhi } \\
\text { Kinerja Keuangan } \\
\text { Perusahaan }\end{array}$ & $\begin{array}{l}\text { Debt to Equity } \\
\text { Rasio (DER) } \\
\text { sebagai variabel } \\
\text { independen } \\
\text { Return on Assets } \\
\text { (ROA) sebagai } \\
\text { variabel dependen }\end{array}$ & 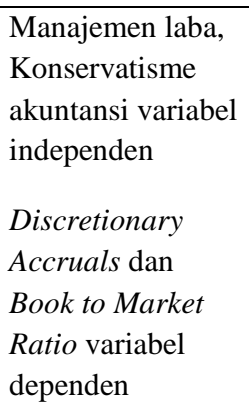 & $\begin{array}{l}\text { Struktur Modal } \\
\text { yang diukur dengan } \\
\text { DER terbukti } \\
\text { berpengaruh negatif } \\
\text { terhadap kinerja } \\
\text { keuangan. }\end{array}$ \\
\hline 12. & $\begin{array}{l}\text { Silalahi \& } \\
\text { Ardini(2017) } \\
\text { ISSN : 2460- } \\
0585\end{array}$ & $\begin{array}{l}\text { engaruh Pengungkapan } \\
\text { Corporate Social } \\
\text { Responsibility, Leverage } \\
\text { dan Ukuran Perusahaan } \\
\text { Terhadap Kinerja Keuangan }\end{array}$ & $\begin{array}{l}\text { Corporate Sosial } \\
\text { Responsibility dan } \\
\text { Debt to Equity } \\
\text { Rasio (DER) } \\
\text { sebagai variabel } \\
\text { independen }\end{array}$ & $\begin{array}{l}\text { Ukuran } \\
\text { Perusahaan } \\
\text { variabel } \\
\text { independen }\end{array}$ & $\begin{array}{l}\text { Pengungkapan } \\
\text { CSR } \\
\text { berpengaruh } \\
\text { positif dan } \\
\text { signifikan } \\
\text { terhadap kinerja } \\
\text { keuangan. }\end{array}$ \\
\hline
\end{tabular}




\begin{tabular}{|c|c|c|c|c|c|}
\hline \multirow{2}{*}{ No } & \multirow{2}{*}{$\begin{array}{l}\text { Nama dan } \\
\text { Tahun } \\
\text { Penelitian }\end{array}$} & \multirow{2}{*}{ Judul Penelitian } & \multicolumn{2}{|c|}{ Variabel } & \multirow{2}{*}{ Hasil Penelitian } \\
\hline & & & Persamaan & Perbedaan & \\
\hline & & & $\begin{array}{l}\text { Return on } \\
\text { Assets }(\mathrm{ROA}) \\
\text { sebagai variabel } \\
\text { dependen }\end{array}$ & & $\begin{array}{ll}\text { 2. } & \text { DER berpengaruh } \\
\text { negatif dan } \\
\text { signifikan } \\
\text { terhadap kinerja } \\
\text { keuangan. } \\
\text { 3. } \\
\text { Secara simultan, } \\
\text { pengungkapan } \\
\text { CSR dan DER } \\
\text { berpengaruh dan } \\
\text { signifikan } \\
\text { terhadap kinerja } \\
\text { keuangan (ROA). }\end{array}$ \\
\hline 14. & $\begin{array}{l}\text { Suciwati,Desak } \\
\text { Putu (2016) }\end{array}$ & $\begin{array}{l}\text { Pengaruh Corporate Sosial } \\
\text { Responsilbility Terhadap } \\
\text { Kinerja Keuangan (Pada } \\
\text { Perusahaan Sektor } \\
\text { Pertambangan di BEI Tahun } \\
\text { 2010-2013) }\end{array}$ & $\begin{array}{l}\text { Corporate Sosial } \\
\text { Responsibility } \\
\text { sebagai variabel } \\
\text { independen } \\
\text { Return on Asset } \\
\text { sebagai variabel } \\
\text { dependen }\end{array}$ & $\begin{array}{l}\text { Return on Equit } \\
\text { (ROE) sebagai } \\
\text { variabel dependen }\end{array}$ & $\begin{array}{lr}\text { CSR } & \text { disclosure } \\
\text { berpengaruh positif } \\
\text { dan } & \text { signifikan } \\
\text { terhadap } & \text { ROA dan } \\
\text { ROE. } & \end{array}$ \\
\hline 15. & $\begin{array}{l}\text { Yaparto,dkk } \\
\text { (2013) }\end{array}$ & $\begin{array}{l}\text { Pengaruh Corporate Social } \\
\text { Responsibility Terhadap } \\
\text { Kinerja Keuangan Pada } \\
\text { Sektor Manufaktur Yang } \\
\text { Terdaftar Di Bursa Efek } \\
\text { Indonesia Pada Periode } \\
\text { 2010-2011 }\end{array}$ & $\begin{array}{l}\text { Corporate Sosial } \\
\text { Responsibility } \\
\text { sebagai variabel } \\
\text { independen } \\
\\
\text { Return on Asset } \\
\text { sebagai variabel } \\
\text { dependen }\end{array}$ & $\begin{array}{l}\text { Return on Equit } \\
\text { (ROE) dan } \\
\text { Earning Per } \\
\text { Share (EPS) } \\
\text { sebagai variabel } \\
\text { dependen }\end{array}$ & $\begin{array}{l}\text { CSR tidak } \\
\text { memberikan } \\
\text { pengaruh dan } \\
\text { signifikan terhadap } \\
\text { ROA, ROE, dan } \\
\text { EPS. }\end{array}$ \\
\hline
\end{tabular}

\section{Hasil Analisis}

\subsection{Model Analisis Data}

Dalam penelitian ini model analisis yang digunakan adalah regresi berganda karena penelitian ini dirancang untuk meneliti pengaruh variabel independen dan variabel dependen. Rumus yang digunakan untuk menentukan persamaan regresi berganda adalah sebagai berikut:

$$
\mathbf{Y}=\mathbf{a}+\mathbf{b}_{1} \mathbf{X}_{1}+\mathbf{b}_{2} \mathbf{X}_{2}+\mathbf{e}
$$

$$
\begin{aligned}
& \text { Keterangan: } \\
& \text { Y = Profitability } \\
& \text { a = Nilai Konstanta } \\
& b_{1, . .} b_{n}=\text { Nilai Koefisien Regresi } \\
& \mathrm{X}_{1} \quad=\text { Pengungkapan Corporate Social } \\
& \text { Responsibility } \\
& \mathrm{X}_{2} \quad=\text { Debt Equity Ratio } \\
& \text { e = Error Term }
\end{aligned}
$$

\subsection{Teknik Analisis Data}

Penelitian menggunakan pendekatan kuantitatif dan metode analisis yang digunakan dalam penelitian ini yaitu analisis statistik yang perhitungannya dilakukan dengan menggunakan SPSS 
(Statistical Product and Service Solution) Versi 20.0. Analisis ini bertujuan untuk menentukan pengaruh hubungan antara index pengungkapan Corporate Social Responsibility (CSR) dan Debt Equity Ratio (DER) terhadap Profitability.

\section{Pembahasan}

\subsection{Statistik Deskriptif}

Variabel dari penelitian ini terdiri dari Corporate Social Responsibility dan Debt Equity Ratio sebagai variabel independen dan Profitability sebagai variabel dependen. Berikut ini tabel 4.1 yang berisi hasil perhitungan statistik deskriptif dan data penelitian yang disajikan dalam bentuk tabel sebagai berikut:

\section{Tabel 4.1}

\section{Statistik Deskriptif}

\begin{tabular}{|l|r|r|r|r|r|}
\hline & $\mathrm{N}$ & Minimum & Maximum & Mean & $\begin{array}{c}\text { Std. } \\
\text { Deviation }\end{array}$ \\
\hline CSR & 72 &, 179 &, 872 &, 50744 &, 174856 \\
DER & 72 &, 169 & 3,923 & 1,05061 &, 917608 \\
Profitability & 72 &, 000 &, 290 &, 08174 &, 062841 \\
Valid N & 72 & & & & \\
(listwise) & & & & & \\
\hline
\end{tabular}

Sumber: Data Sekunder diolah melalui SPSS Versi 20, 2018

Jika dilihat dari variabel independen $\left(\mathrm{X}_{1}\right)$ yaitu CSR memiliki nilai minimum sebesar 0,179 atau 17,9\% pada perusahaan PT BSSR (Baramulti Sukses Sarana Tbk.) periode 2014, nilai maximum sebesar 0,872 atau $87,2 \%$ pada perusahaan PTBA (Tambang Batu Bara Bukit Asam (Persero) Tbk.) periode 2012 dan perusahaan PT TINS (Timah (Persero) Tbk.) periode 2012, dan nilai mean sebesar 0,50744 atau 50,7\%, berarti perusahaan pertambangan sudah cukup banyak mengungkapkan CSR karena telah mencapai rata-rata standar CSR yaitu sebesar 50\% digunakan untuk meningkatkan Profitability perusahaan pertambangan.

Sedangkan pada variabel independen $\left(\mathrm{X}_{2}\right)$ yaitu DER memiliki nilai minimum sebesar 0,169 atau $16,9 \%$ pada perusahaan PT KKGI (Resource Alam Indonesia Tbk.) periode 2016, nilai maximum sebesar 3,923 atau 392,3\% pada perusahaan PT RUIS (Radiant Utama Interinsco Tbk.) periode 2012, dan nilai mean sebesar 1,05061 atau $105 \%$, berarti perusahaan pertambangan lebih dominan menggunakan DER untuk membiayai kegiatan operasi perusahaan untuk meningkatkan Profitability namun mean yang diperoleh dalam penelitian ini telah melebihi batas standar industri yaitu sebesar $80 \%$ dan dianggap tidak baik bagi perusahaan.

\subsection{Uji Normalitas}

Uji normalitas bertujuan untuk menguji apakah dalam sebuah regresi, variabel independen maupun variabel dependen mempunyai distribusi normal atau tidak mempunyai distribusi normal. Pengujian normalitas didalam penelitian ini menggunakan uji KolmogorovSmirnov. Data yang berdistribusi normal ditunjukkan dengan nilai signifikan diatas 0.05 atau $5 \%$.

Tabel 4.2.

Uji Normalitas

Data Kolmogorov-Smirnov Test

(Sebelum Data Ditransform)

One-Sample Kolmogorov-Smirnov Test

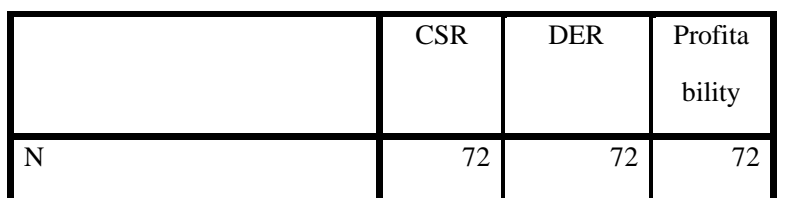




\begin{tabular}{ll|r|r|r} 
Normal & Mean &, 50744 & 1,05061 &, 08174 \\
Parameters $^{\mathrm{a}, \mathrm{b}}$ & Std. Deviation &, 174856 &, 917608 &, 062841 \\
& Absolute &, 114 &, 237 &, 106 \\
Most & Positive &, 114 &, 237 &, 106 \\
Extreme &,- 099 &,- 174 &,- 097 \\
Differences & Negative &, 968 & 2,013 &, 895 \\
& Kolmogorov-Smirnov Z &, 306 &, 001 &, 399 \\
Asymp. Sig. (2-tailed) & &
\end{tabular}

a. Test distribution is Normal.

b. Calculated from data

Sumber: Data Sekunder diolah melalui SPSS Versi 20, 2018

Berdasarkan hasil uji normalitas Kolmogorov-Smirnov setelah data ditransform menunjukkan bahwa variabel DER yang memiliki nilai KolmogorovSmirnov sebesar 1,349 atau 134,9\% dengan nilai signifikan sebesar 0,054 atau $5,4 \%$ yang berarti variabel DER telah terdistribusi secara normal. Hal ini dapat disimpulkan bahwa nilai-nilai untuk setiap variabel independen dan variabel dependen menunjukkan terdistribusi normal yang dapat dilihat bahwa nilai signifikan semua variabel melebihi 0,05 atau $5 \%$.

\subsection{Heteroskedastisitas}

Uji heteroskedastisitas bertujuan untuk menguji apakah dalam model regresi terjadi ketidaksamaan variance dari residual atau pengamatan ke pengamatan yang lain. Pengujian dalam penelitian ini dilakukan dengan uji grafik Scatter Plot berikut

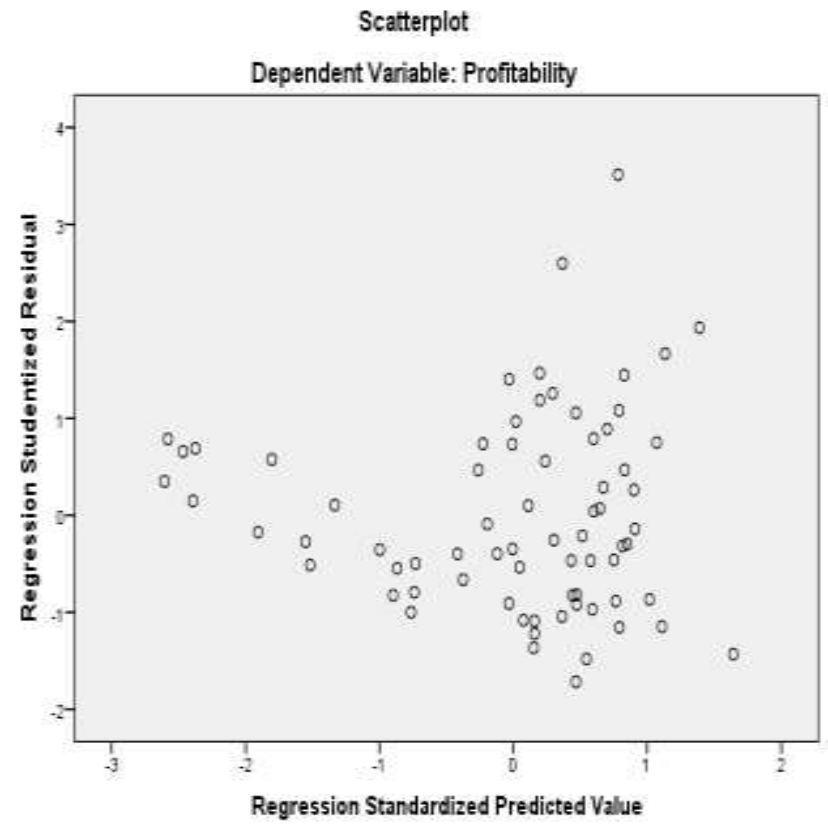

Berdasarkan gambar 4.3. diatas menunjukkan hasil uji heteroskedastisitas tidak terdapat pola yang jelas serta titiktitik menyebar diatas dan di bawah angka nol pada sumbu Y, titik-titik tidak mengumpal hanya diatas atau dibawah saja, penyebaran titik-titik data tidak berpola sehingga dapat disimpulkan bahwa pada model regresi ini tidak terjadi heteroskedastisitas.

\subsection{Uji Multikolinearitas}

Uji multikolinearitas bertujuan untuk menguji apakah model regresi ditemukan adanya korelasi antar variabel bebas atau variabel independen.

Tabel 4.4

Uji Multikolinearitas

\begin{tabular}{|c|c|c|c|c|c|c|c|}
\hline \multirow[t]{2}{*}{ Model } & \multicolumn{2}{|c|}{$\begin{array}{l}\text { Unstandardized } \\
\text { Coefficients }\end{array}$} & \multirow{2}{*}{$\begin{array}{c}\text { Standardized } \\
\text { Coefficients }\end{array}$} & \multirow[t]{2}{*}{$\mathrm{t}$} & \multirow[t]{2}{*}{ Sig. } & \multicolumn{2}{|c|}{ Collinearity Statistics } \\
\hline & $\mathrm{B}$ & Std. Error & & & & Tolerance & VIF \\
\hline (Constant) & , 108 & 030 & & 3,633 &, 001 & & \\
\hline 1 CSR & ,089 & 037 &, 247 & 2,369 & ,021 &, 878 & 1,139 \\
\hline DER &,- 075 & 017 &,- 451 & $-4,333$ &, 000 & ,878 & 1,139 \\
\hline
\end{tabular}

a. Dependent Variable: Profitability

Sumber: Data Sekunder diolah melalui SPSS Versi 20, 2018 
Berdasarkan tabel diatas, hasil uji multikolinearitas menunjukkan nilai VIF sebesar 1,139 yang berarti model regresi yang digunakan dapat dipercaya dan objektif karena nilai VIF kurang dari 10 dan nilai tolerance yang diperoleh yaitu sebesar 0.878 yang berarti melebihi 0.10 . Hal ini dapat disimpulkan bahwa model regresi dalam penelitian ini tidak terjadi gejala multikolinearitas.

\subsection{Uji Autokorelasi}

Hasil pengujian autokorelasi pada penelitian ini dapat dilihat pada tabel Model Summary berikut.

\section{Tabel 4.5}

\section{Uji Autokorelasi}

Model Summary ${ }^{b}$

\begin{tabular}{|l|c|r|r|r|r|}
\hline Model & $\mathrm{R}$ & R Square & $\begin{array}{c}\text { Adjusted R } \\
\text { Square }\end{array}$ & $\begin{array}{l}\text { Std. Error of } \\
\text { the Estimate }\end{array}$ & $\begin{array}{r}\text { Durbin- } \\
\text { Watson }\end{array}$ \\
\hline 1 &, $585^{\mathrm{a}}$ &, 342 &, 323 &, 051691 &, 835 \\
\hline
\end{tabular}

a. Predictors: (Constant), DER, CSR

b. Dependent Variable: Profitability

Sumber: Data Sekunder diolah melalui SPSS Versi 20, 2018

Berdasarkan tabel diatas menunjukkan bahwa nilai Durbin-Watson (DW) sebesar 0,835. Menurut Silalahi dan Ardini (2017:12) apabila nilai DW terletak antara -2 dan $+2(-2<0,835<+2)$ maka tidak terjadinya masalah autokorelasi.

\subsection{Hasil Pengujian Hipotesis}

\subsubsection{Pengaruh Pengungkapan CSR Terhadap Profitability}

Hasil pengujian hipotesis pengaruh pengungkapan CSR terhadap profitability pada penelitian ini dapat dilihat pada tabel berikut:
Tabel 4.6.1.

Uji t (Secara Parsial)

Coefficients $^{\mathrm{a}}$

\begin{tabular}{|c|c|c|c|c|c|}
\hline \multirow[t]{2}{*}{ Model } & \multicolumn{2}{|c|}{$\begin{array}{l}\text { Unstandardized } \\
\text { Coefficients }\end{array}$} & $\begin{array}{l}\text { Standardized } \\
\text { Coefficients }\end{array}$ & \multirow[t]{2}{*}{$\mathrm{t}$} & \multirow[t]{2}{*}{ Sig. } \\
\hline & B & $\begin{array}{l}\text { Std. } \\
\text { Error }\end{array}$ & Beta & & \\
\hline (Constant) & , 108 & ,030 & & 3,633 & ,001 \\
\hline CSR & 089 & ,037 & ,247 & 2,369 & 021 \\
\hline
\end{tabular}

a. Dependent Variable: Profitability

Sumber: Data Sekunder diolah melalui SPSS Versi 20, 2018

Hipotesis 1:

$\mathrm{H}_{0} \quad$ : Tidak ada pengaruh dan signifikan pengungkapan CSR terhadap Profitability

$\mathrm{H}_{1}$ : Ada pengaruh positif dan signifikan pengungkapan CSR terhadap Profitability

Berdasarkan hasil perhitungan, diketahui bahwa pengungkapan CSR memiliki nilai thitung sebesar 2,369 dan ttabel sebesar 1,666, dengan kata lain thitung > ttabel $(2,369>1,666)$ dan nilai signifikan sebesar 0,021 $(0,021<0,050)$, maka H0 ditolak dan $\mathrm{H} 1$ diterima. Jadi dapat disimpulkan bahwa pengungkapan CSR berpengaruh positif dan signifikan terhadap Profitability perusahaan pertambangan di Bursa Efek Indonesia periode 2012-2017.

\subsubsection{Pengaruh Pengungkapan DER Terhadap Profitability}

Hasil pengujian hipotesis pengaruh DER terhadap profitability pada penelitian ini dapat dilihat pada tabel berikut:

Tabel 4.6.2.

\section{Uji t (Secara Parsial)}

Coefficients $^{\mathrm{a}}$

\begin{tabular}{|l|c|c|c|c|}
\hline Model & $\begin{array}{c}\text { Unstandardized } \\
\text { Coefficients }\end{array}$ & $\begin{array}{c}\text { Standardized } \\
\text { Coefficients }\end{array}$ & $\mathrm{t}$ & Sig. \\
\hline
\end{tabular}




\begin{tabular}{|c|c|c|c|c|c|}
\hline & B & Std. Error & Beta & & \\
\hline (Constant) &, 108 & ,030 & & 3,633 & ,00 \\
\hline DER &,- 075 & ,017 &,- 451 & $-4,333$ & ,00 \\
\hline
\end{tabular}

a. Dependent Variable: Profitability

Sumber: Data Sekunder diolah melalui SPSS Versi 20, 2018

Hipotesis 2:

$\mathrm{H}_{0}$ : Tidak ada pengaruh dan signifikan DER terhadap Profitability.

$\mathrm{H}_{2}$ : Ada pengaruh negatif dan signifikan DER terhadap Profitability.

Variabel DER memiliki nilai thitung sebesar $-4,334$ dan tabel sebesr 1,666 , dengan kata lain thitung > ttabel ($4,334>1,666)$ dengan nilai signifikan sebesar 0,000 $(0,000<0,050)$ maka H0 ditolak dan $\mathrm{H} 2$ diterima, yang artinya DER berpengaruh negatif dan signifikan terhadap Profitability perusahaan pertambangan di Bursa Efek Indonesia periode 2012-2017.

\subsubsection{Pengaruh Pengungkapan CSR dan} DER Terhadap Profitability

Sedangkan hasil pengujian hipotesis secara simultan pada penelitian ini dapat dilihat pada kedua tabel berikut:

Tabel 4.6.3.

\section{Uji t (Secara Parsial)}

ANOVA ${ }^{\mathrm{a}}$

\begin{tabular}{|r|r|r|r|r|r|}
\hline Model & $\begin{array}{r}\text { Sum of } \\
\text { Squares }\end{array}$ & Df & $\begin{array}{c}\text { Mean } \\
\text { Square }\end{array}$ & F & Sig. \\
\hline Regression &, 096 & 2 &, 048 & 17,965 &, $000^{\mathrm{b}}$ \\
$1 \quad$ Residual &, 184 & 69 &, 003 & & \\
$\quad$ Total &, 280 & 71 & & & \\
\hline
\end{tabular}

a. Dependent Variable: Profitability

b. Predictors: (Constant), DER, CSR

Sumber: Data Sekunder diolah melalui SPSS Versi 20,2018
Hipotesis 3:

$\mathrm{H}_{0}$ : Tidak ada pengaruh dan signifikan pengungkapan CSR dan DER terhadap Profitability.

$\mathrm{H}_{3}$ : Ada pengaruh positif dan signifikan pengungkapan CSR dan DER terhadap Profitability.

Berdasarkan hasil perhitungan diketahui bahwa kedua variabel independen memiliki nilai Fhitung sebesar 17,971 dengan nilai probabilitas (sig.F) sebesar 0,000. Hasil uji-F dengan signifikan $(\alpha) \leq 5 \%$, df $1=2$, df $2=70$, maka diketahui nilai Ftabel adalah 3,130. Hal ini menunjukkan bahwa Fhitung> Ftabel $(17,971>3,310)$. Hasil ini menunjukkan bahwa pengaruh CSR dan DER secara simultan berpengaruh positif dan signifikan terhadap Profitability perusahaan pertambangan di Bursa Efek Indonesia periode 2012-2017.

\subsection{Uji Koefisien Determinasi $\left(\mathbf{R}^{2}\right)$}

Untuk mengetahui nilai koefisien determinasi $\left(\mathrm{R}^{2}\right)$ dapat dilihat dari tabel berikut:

\section{Tabel 4.7.}

\section{Koefesien Determinasi}

\begin{tabular}{|l|c|r|r|r|}
\hline Model & $\mathrm{R}$ & $\begin{array}{c}\mathrm{R} \\
\text { Square }\end{array}$ & $\begin{array}{r}\text { Adjusted } \\
\text { R Square }\end{array}$ & $\begin{array}{r}\text { Std. Error of } \\
\text { the Estimate }\end{array}$ \\
\hline 1 &, $585^{\mathrm{a}}$ &, 342 &, 323 &, 051691 \\
\hline
\end{tabular}

a. Predictors: (Constant), DER, CSR

b. Dependent Variable: Profitability

Sumber: Data Sekunder diolah melalui SPSS Versi 20,2018

Berdasarkan tabel di atas, diketahui bahwa koefisien determinasi $\left(\mathrm{R}^{2}\right)$ adalah sebesar 0,323 atau $32,3 \%$ artinya kombinasi variabel independen yang 
terdiri dari pengungkapan $\operatorname{CSR}\left(\mathrm{X}_{1}\right)$ dan DER $\left(\mathrm{X}_{2}\right)$ terhadap variabel dependen yaitu Profitability(Y) sebesar $32,3 \%$ dan sisanya sebesar $67,7 \%$ dipengaruhi oleh variabel-variabel lain yang tidak diteliti dalam penelitan ini.

\section{Kesimpulan dan Saran}

\subsection{Kesimpulan}

Berdasarkan rumusan masalah yang disusun oleh penulis, maka dapat diambil kesimpulan sebagai berikut:

\section{Pengungkapan Corporate Social} Responsibility berpengaruh positif dan signifikan terhadap Profitability pada perusahaan pertambangan di Bursa Efek Indonesia periode 2012-2017.

2. Debr Equity Ratio berpengaruh negatif dan signifikan terhadap Profitability pada perusahaan pertambangan di Bursa Efek Indonesia periode 2012-2017.

3. Pengungkapan CSR dan DER berpengaruh positif dan signifikan terhadap Profitability pada perusahaan pertambangan di Bursa Efek Indonesia periode 2012-2017.

\subsection{Implikasi Manajerial}

Berdasarkan hasil analisis pembahasan serta kesimpulan penelitian ini, berikut implikasi manajerial yang diharapkan dapat menjadibahan bagi perusahaan pertambangan, antara lain sebagai berikut:

1. Perusahaan pertambangan harus menerapkan konsep triple bottom line dimana selain mengejar keuntungan (profit) suatu perusahaan juga memperhatikan kesejahteraan masyarakat (people) serta ikut berkontribusi aktif dalam menjaga kelestarian lingkungan (planet) sesuai dengan peraturan UndangUndang No.40 tahun 2007 dan UndangUndang No.25 tahun 2007. Karena dapat disimpulkan bahwa jika adanya peningkatan dalam pengungkapan CSR maka Profitability juga mengalami peningkatan. Karena perusahaan pertambangan telah menyadari manfaat dari pengungkapan CSR bagi stakeholders yang meningkatkan citra/reputasi perusahaan dan kredibilitas serta dapat dijadikan sebagai pengambilan keputusan bagi investor untuk menginvestasikan sahamnya pada perusahaan pertambangan.

2. Dilihat dari sifat dan karakteristik perusahaan pertambangan yaitu padat modal dan padat risiko juga memicu tingginya dana yang dikeluarkan. Namun sebaiknya tingkat DER tidak melebihi standar industri menurut Kasmir (2016) yaitu sebesar 80\% hal ini berkaitan dengan biaya bunga yang harus dibayarkan yang tentu saja akan menurunkan profitability. Selain itu, akan lebih aman bagi kreditor apabila memberikan pinjaman kepada debitor yang memiliki DER yang rendah karena hal ini berarti akan semakin besar jumlah modal pemilik yang dapat dijadikan sebagai jaminan.

\subsection{Saran}

Berdasarkan hasil analisis pembahasan serta beberapa simpulan dan keterbatasan pada penelitian ini, adapun saran-saran yang dapat diberikan melalui hasil penelitian ini agar mendapatkan hasil yang lebih baik, yaitu:

1. Bagi perusahaan

Menerbitkan laporan keberlanjutan (Sustainability Report) dalam 
pengungkapan CSR karena dalam laporan tersebut dapat mencerminkan kondisi perusahaan yang lebih baik dalam menggambarkan pertanggungjawaban perusahaan terhadap lingkungan.

2. Bagi Peneliti Selanjutnya
a. Menggunakan indikator pengungkapan CSR lainnya.
b. Menambah dan memodifikasi variabel-variabel penelitian.
c. Menggunakan proksi profitability yang lainnya.

\section{Daftar Pustaka}

Adhiwardana, E. S., \& Daljono. (2013). Pengaruh Corporate Social Responsibility dan Kepemilikan Asing Terhadap Kinerja Perusahaan (Studi Empiris pada Perusahaan Manufaktur yang Terdaftar di Bursa Efek Indonesia). Http://ejournal-

s1.undip.ac.id/index.php/accountin $g$, Volume 2(No 2), 1-12.

Andreas, H. H., Sucahyo, U. S., \& Elisabeth, D. (2015). Corporate Sosial Responsibility dan Profitabilitas. Jurnal Manajemen, Volume 15(No 1), 119-136.

Arifin, Z. (2005). Teori Keuangan dan Pasar Modal. Yogyakarta: Ekonosia.

Bhernadha, Y. A., Topowijono, \& Azizah, D. F. (2017). Pengaruh Corporate Social Responsibility Terhadap Kinerja Keuangan Perusahaan (Studi Pada Perusahaan Winner Of Sustainability Reporting Award (Sra) 2015 Yang Terdaftar di PT BEI Periode 20102014). Jurnal Administrasi (JAB), Volume 44(No 1).
Brigham, E. F., \& Houaton, J. F. (2001). Manajemen Keuangan. Jakarta: Erlangga.

Binangkit, A. B., \& Raharjo, S. (2014). Pengaruh Struktur Modal Terhadap Kinerja Perusahaan dan Harga Saham Pada Perusahaan Manufaktur di Bursa Efek Indonesia. AKTUAL, Volume 1(2), 24-34.

Bulan, A. A. A. T., \& Astika, I. B. P. (2014). Moderasi Corporate Social Responsibility Terhadap Pengaruh Kinerja Keuangan Pada Nilai Perusahaan. E-Jurnal Akuntansi Universitas Udayana, Volume 2, 136-151.

Dewi, W. A. (2015). Hubungan Corporate Sosial Responsibility Dengan Kinerja Keuangan Pada Perusahaan Sektor Pertanian dan Pertambangan Di Bursa Efek Indonesia. Tesis. Sekolah Pascasarjana. Bogor.

Fadhilah, A. (2012). Pengaruh Struktur Modal Terhadap Kinerja Keuangan Perusahaan (Studi kasus Pada Perusahaan Sektor Pertambangan Yang Tercatat Di Bursa Efek Indonesia 2005-2011). Kajian Ekonomi Dan Keuangan, Volume 16(No 1), 2005-2011.

Fahmi, I. (2013). Analisis Laporan Keuangan. Bandung: Alfabet

(2013). Etika Bisnis (Teori,Kasus,dan Solusi). Bandung: Alfabeta.

Feri, M. (2013). Pengaruh Rasio Profitabilitas Terhadap Perubahan Harga Saham Pada Perusahaan Sektor Properti Yang Listing di Bursa Efek Indonesia Periode 
2008-2012. Jurnal Manajemen, Nomor 6, Hal. 1561.

Firdaus, Zamzam Fakhry, 2018 Aplikasi Metodologi, Yogyakarta, Penerbit Deepublish

Gantino, R. (2016). Pengaruh Corporate Social Responsibility Terhadap Kinerja Keuangan Perusahaan Manufaktur yang Terdaftar di Bursa Efek Indonesia periode 2008-2014. Jurnal Dinamika Akuntansi Dan Bisnis, Volume 3(No 2), 19-32.

Ghozali, I. (2013). Aplikasi Analisi Multivariate Dengan Program SPSS 21. Semarang: Badan Penerbit Universitas Diponegoro.

Hamdanai, M. (2014). Hubungan Pengungkapan Corporate Social Responsibility (CSR) Terhadap Kinerja Keuangan dan Harga Saham Pada Perusahaan LQ45. Jurnal Organisasi Dan Manajemen, Volume 10(No.1), 2736.

Hanafi, Mamduh M dan Halim, A. (2016). Analisis Laporan Keuangan. Yogyakarta: UPP STIM YKPN.

Harahap, S. S. (2013). Analisis Kritis atas Laporan Keuangan. Jakarta: PT Raja Grafindo Persada. . (2013). Analisis Kritis atas Laporan Keuangan. Jakarta: Rajawali Pers.

Hery. (2017). Analisis Laporan Keuangan. Jakarta: PT Grasindo.

Kasmir. (2016). Analisis Laporan Keuangan. Jakarta: Rajawali Pers.

Kretarto, A. (2001). Investor Relation: Pemasaran dan Komunikasi
Keuangan Perusahaan Berbasis Kepatuhan, Grafiti Pers.

Kristiana, R. (2014). Kebijakan Utang Sebagai Determinan Kinerja Perusahaan. Jurnal Akuntansi Multiparadigma JAMAL, Volume 5(No 3), 345-510.

Kusdiyanto, \& Kusumaningrum, D. D. (2015). Pengaruh Good Corporate Governance Dan Leverage Terhadap Kinerja keuangan (Studi Pada Perusahaan Manufaktur Yang Terdaftar di BEI Tahun 20132014). BENEFIT Jurnal Managemen Dan Bisnis, Volume 19(No 2), 161-167.

Modigliani, \& Miller, M.H. (1958). The Investment Opportunity Set and Corporate Financing, Dividend, and Competations Policies. American Economic.

Modigliani, \& Miller, M.H. (1963). The Cost of Capital, Corporation Finance, and The Theory of Investment. American Economic.

Mujariah. (2016). Pengaruh Struktur Modal Terhadap Kinerja Keuangan. JOM FiISIP, Volume 3(No 2), 1-15.

Munawir. (2012). Analisa Laporan Keungan. Yogyakarta: Liberty.

Mustafa, C. C., \& Handayani, N. (2014). Pengaruh Pengungkapan Corporate Sosial Responsibility Terhadap Kinerja Keuangan Perusahaan Manufaktur. Jurnal Ilmu \& Riset Akuntansi, Volume 3(No 6).

Nainggolan, I. P. M., \& Prariwi, M. W. (2017). Analisis Faktor-Faktor Yang Mempengaruhi Kinerja Keuangan Perusahaan. Media 
Ekonomi Dan Manajemen, Volume 32(No 1), 80-96.

Nugraha, G. I. K. (2017). Tanggungjawab Sosial Perusahaan (CSR) PT Antam Tbk. (Studi Literatur Aspek Ekonomi, Sosial, dan Lingkungan). https://www.researchgate.net/publi cation/321873947.

Pongoh, M. (2011). Analisis Laporan Keuangan Untuk Menilai Kinerja Keuangan PT Bumi Resources Tbk. Jurnal EMBA, Volume 1(No. 3), 669-679.

Purba, I. A. C., \& Suaryana, I. G. N. A. (2018). Kualitas Laporan Keuangan, Asimetri Informasi dan Efisiensi Investasi Pada Perusahaan Pertambangan. Jurnal Ilmiah Akuntansi Dan Bisnis, Volume 13(No.1), 42-53.

Ross, S.A., Westerfield., Randolph, W., \& Jordan, J. (2010). Corporate Finance Fundamentals, $7^{\text {th }}$ edision. New York: Mc Graw Hill.

Santoso, I. (2007). Akuntansi Keuangan Menengah. Bandung: PT Refika Aditama.

Sembiring, E. R. (2005). Karakteristik Perusahaan dan Pengungkapan Tanggunjawab Sosial: Study Empiris Pada Perusahaan yang Terdaftar di Bursa Efek Indonesia. SNA VIII Solo, 15 - 16 September 2005, (September), 15-16.

Silalahi, A. C., \& Ardini, L. (2017). Pengaruh Pengungkapan Corporate Social Responsibility, Leverage dan Ukuran Perusahaan Terhadap Kinerja Keuangan, Volume 6(No 8), 1-18.

Suciwati, Desak Putu, D. (2016). Pengaruh
Corporate Sosial Responsilbility Terhadap Kinerja Keuangan (Pada Perusahaan Sektor Pertambangan di BEI Tahun 2010-2013). Jurnal Bisnis Dan Kewirausahaan, Volume 12(No 2), 104-113.

Sugiyono. (2013). Metode Penelitian Bisnis. Bandug: CV Alfabeta.

Tiarasandy, A., Yuliandari, W. S., \& Triyanto, D. N. (2018). Pengaruh Kinerja Lingkungan dan Corporate Social Responsibility Terhadap Kinerja Finansial (Studi empiris Pada Perusahaan yang Terdaftar di PROPER Periode 2013-2015). EProceeding of Management, Volume 5(No 1), 678-688.

Undang-Undang Republik Indonesia Nomor 4 Tahun 2009 tentang Mineral dan Batubara, 2009

Undang-Undang Republik Indonesia Nomor 40 Tahun 2007 tentang Mineral dan Batubara, 2007

Undang-Undang Republik Indonesia Nomor 25 Tahun 2009 tentang Mineral dan Batubara, 2009

www.idx.co.id (diakses Februari 2018) www.kompasiana.com (diakses Mei 2018) www.pwc.com (diakses Mei 2018)

www.sahamok.com (diakses Februari 2018)

Yaparto, M., Frisko, D., \& Eriandani, R. (2013). Pengaruh Corporate Social Responsibility Terhadap Kinerja Keuangan Pada Sektor Manufaktur Yang Terdaftar Di Bursa Efek Indonesia Pada Periode 2010-2011. Jurnal Ilmiah Mahasiswa Universitas Surabaya, Volume 2(No 1), 1-19. 
Zamzam, Fakhry, Havis Aravik, 2016.

Manajemen SDM Berbasis

Syariah, Bogor: CV. RWTC

Success

Zamzam, Fakhry, 2015, Teknik Dasar Penulisan Proposal Tesis,

Palembang, Penerbit Noerfikri 